\title{
Elasticities of Electricity Demand in Urban
}

\section{Indian Households}

\author{
By
}

Massimo Filippini, Centre for Energy Policy and Economics, Swiss Federal Institute of Technology Zürich and Department of Economics, Università della Svizzera Italiana, Lugano

Shonali Pachauri ${ }^{1}$, Centre for Energy Policy and Economics, Swiss Federal Institute of Technology Zürich.

\footnotetext{
${ }^{1}$ Corresponding author: Shonali Pachauri, ETH Zentrum, WEC, CH-8092 Zürich, Switzerland.
} 


\begin{abstract}
In the past, several electricity demand studies have been published for India based on aggregate macro data at the country or sub-national/state level. Since the underlying theory of consumer demand is based on the behaviour of individual agents, the use of micro data, which reflects individual and household behaviour, more closely, can shed greater light on the nature of consumer responses. In this paper, seasonal price and income elasticities of electricity demand in the residential sector of all urban areas of India are estimated for the first time using disaggregate level survey data for about thirty thousand households. Three electricity demand functions have been econometrically estimated using monthly data for the winter, monsoon and summer season in order to understand the extent to which factors like income, prices, household size and other household specific characteristics, influence variations observed in individual households' electricity demand. The results show electricity demand is income and price inelastic in all three seasons, and that household, demographic and geographical variables are significant in determining electricity demand.
\end{abstract}

Key Words India, residential electricity use, demand analysis, price and income elasticities

Short Title Electricity demand in Indian households

Acknowledgements: The authors would like to gratefully acknowledge the National Sample Survey Organisation, Department of Statistics of the Government of India, for making available to us the unit level, household survey data. We would also like to thank Prof. Daniel Spreng at the Centre for Energy Policy and Economics for his support of our research, and an anonymous referee for his useful comments. All errors and omissions remain with the authors. 


\section{Introduction}

Over the past few decades' significant changes have taken place in the electricity sector in India. Total electricity consumption in India grew from 44 TWh in 1971 to 314 TWh in 1999 at an annual rate of growth of $7.4 \%$ for this period (CSO, 2000). Electricity demand in the Indian household sector has also been growing at a very rapid rate over the last decades. According the Tata Energy Data Directory and Yearbook, the consumption of electricity per household went up from 7 to $53 \mathrm{kWh}$ between 1970-71 and 1994-95 (TERI, 1999) The share of electricity consumption from utilities in the domestic sector has also risen from about $11 \%$ in the early eighties to nearly $18 \%$ by the early nineties (CMIE, 1996). Given, current trends in population growth, industrialisation, urbanisation, modernisation and income growth, electricity consumption is expected to increase substantially in the coming decades as well. This implies enormous new financial investments will be needed to meet demand in this sector.

Currently, the electricity sector is characterised by chronic power shortages and poor power quality. With demand exceeding supply, severe peak and energy shortages continue to plague the sector. While the government opened up the power generation sector to private investments in 1991, the State Electricity Boards (SEBs) continue to be the main agencies responsible for the generation and supply of electricity in India today. The elementary problem being faced by the power sector is the poor financial conditions of these State Electricity Boards. This has resulted in inadequate investment in additional generation capacity, which is likely to further exacerbate the existing gap between supply and demand.

Clearly, there is a large role and potential for demand side management (DSM) programmes in India. The Government of India, through new Energy Conservation legislation is seeking to implement a host of such programmes within the country. One of the key elements of the DSM programmes is the introduction of rational cost-of-service based tariffs 
for power within the country. The price of power is currently set by the State in India and a high degree of cross-subsidization between sectors continues to exist, with average electricity tariffs being generally below the costs of power generation and distribution (see Table 1 below). This has tended to encourage inefficient use of electricity in the subsidized domestic sectors. A revision of electricity tariff rates is thus urgently needed.

\section{Table 1: Consumer category - wise average electricity tariffs in Paise/Kwh}

The case for tariff reform in India is thus clear. However, the effects of any price revisions on consumption will depend on the price elasticity of demand for electricity. Moreover, information regarding the income elasticity of demand for electricity is also of importance, especially in the case of a rapidly developing country like India where one can expect to see large increases in the income of households in the next decades. In the past, electricity demand studies for India published in international journals have been based on aggregate macro data at the country or sub-national/ state level ${ }^{2}$. Some authors have recently shown that the use of micro-level data, which reflects individual and household behaviour more closely, can add detail to an understanding of the nature of consumer responses ${ }^{3}$. Microeconomic approaches to energy and electricity demand modelling also enable an analysis across different heterogeneous household groups and allow for the incorporation of a wide variety of household characteristics within the estimated equations. In other words, the use of micro-level data permits more extensive examination of variation in electricity consumption across demographic and geographic subgroups.

\footnotetext{
${ }^{2}$ See for instance Bose \& Shukla (1999), Sengupta (1993), Roy, (1992), Uri (1979).

${ }^{3}$ See for instance D. Hawdon (1992), Nesbakken (1999).
} 
The literature on electricity demand estimation for the residential sector in India that makes use of micro data is scanty. To our knowledge the only published study is one that estimates the short-term price and income elasticity of residential electricity demand using household survey data for the city of Bombay (Tiwari, 2000). There are very few studies from other developing countries as well that estimate electricity demand by making use of micro household data. Jung (1993) is one example, which presents results from the estimation of an ordered logit model making use of micro census data from Korea. Other recent examples of studies using micro datasets are from the OECD countries, such as Sweden (Andersson and Damsgaard, 2000), and Denmark (Leth-Petersen, 2001).

In this paper, price and income elasticities of electricity demand in the residential sector of all urban areas of India are estimated for the first time using disaggregate household level survey data. Following Filippini (1999), we econometrically estimate electricity demand functions for urban Indian households using household data on total household expenditure (as a proxy for income), monetary expenditure on electricity and physical quantity of electricity consumed, average price of electricity, and a number of other geographic (regional dummy variables) and socio-economic variables (such as household size, age of the head of the household). The objective of undertaking such estimation is to contribute to an understanding of the key factors that influence electricity demand at the household level in India. The focus is on urban households because many rural households still do not have access to electricity in India and even for those who do, low incomes and lack of market accessibility, mean very low or even negligible electricity consumption. There is also evidence of substantial disparities between rural and urban areas. A recent survey carried out for rural areas in India reports that only $25 \%$ of villages have access to tap water, and only 43\% have domestic lighting (NCAER 1999). 
In addition to the large differences in energy consumption between urban and rural households, there is substantial variation in the quantum and pattern of energy consumption depending on income levels, climate and geography and local fuel resources. Substantial inter-State variability in power or electricity consumption per capita is also evident. Data for 1993-94 reveal that the highest per capita power consumption is in the Western region followed by the Southern, Northern, Eastern and North-Eastern regions (see Table A in the appendix for a list of States included in each region).

India has mainly three seasons a year- monsoon (June-September), summer (MarchJune), and winter (mid October-February). Due to the fact that household electricity consumption in India shows seasonal variation over the year because of differences in the weather, three electricity demand functions have been estimated using monthly data for the three main seasons.

In the following section, the theoretical framework and the empirical specification of the electricity demand model will be specified. The data used in the analysis and the statistical results will then be presented. Some concluding remarks follow in the last section of the paper.

\section{An electricity demand model}

The residential demand for electricity is a demand derived from the demand for a well-lit house, cooked food, hot water, etc., and can be specified using the basic framework of 
household production theory ${ }^{4}$. According to this theory, households purchase "goods" on the market which serve as inputs that are used in production processes, to produce the "commodities" which appear as arguments in the household's utility function. In our specific case, a household combines electricity and capital equipment to produce a composite energy commodity.

Following the household production theory, in this study, we use a single equation approach to modelling the residential demand for electricity in three different seasons: winter, summer and monsoon. We postulate that the demand for electricity depends on the price of electricity, the prices of alternate fuels, income and some demographic and geographic variables.

The general empirical model for each of the three seasons, can be represented by the following demand function:

$$
E=E\left(P_{E}, P_{K}, P_{G}, Y, A D, D S T, D R 1, D R 2, D R 3, D R 4, D H H S, D A H 1, D A H 2\right)
$$

where

$\mathrm{E} \quad=\quad$ monthly residential electricity consumption per household in $\mathrm{kWh}$;

$\mathrm{P}_{\mathrm{E}} \quad=\quad$ electricity price in Rupees per $\mathrm{kWh}$;

$\mathrm{P}_{\mathrm{K}} \quad=\quad$ kerosene price in Rupees per litre;

$\mathrm{P}_{\mathrm{G}} \quad=\quad$ L.P.G price in Rupees per $\mathrm{kg}$;

$\mathrm{Y} \quad=\quad$ household personal income, approximated by total expenditure;

\footnotetext{
${ }^{4}$ For a clear presentation of the household production theory, see Becker (1975), Muth (1966) and Deaton and
} Muellbauer (1980). See Dubin (1985), Flaig (1990) and Filippini (1999) for an application of household production theory to electricity demand analysis. 
$\mathrm{AD}=$ covered area of the dwelling in square feet;

DST = dummy variable to control for the difference of the size of town on electricity consumption. The value of the dummy variable is equal to 1 in case the household resides in a town with more than 1 million people; otherwise is 0 .

$\mathrm{DRi}=$ dummy variable to control for the effect of regional differences on electricity consumption. The value of this dummy variable is equal to 1 for households living in region $\mathrm{i}(\mathrm{i}=1,2,3,4)$; otherwise is 0 .

DHHS $=$ dummy variable to control for the difference of the size of household (number of household members. The value of the dummy variable is equal to 1 in case the household has more than 6 (median size) members; otherwise is 0 .

DAHi $=$ dummy variable to control for differences in the age of the household head. The value of the dummy variable is equal to 1 in case the age of the head of the household is $\mathrm{i}$ ( $\mathrm{i}=$ less than 30 years, between 30 and 45 years); otherwise is 0 .

The key explanatory variables that influence household electricity demand are thus described in the model above. The total household expenditure or income (Y) of the household is the single most important economic variable that is assumed to determine household electricity demand. The price variables included in the estimated model are the average price for the household ${ }^{5}$. In addition to including average price of electricity $\left(\mathrm{P}_{\mathrm{E}}\right)$, since electricity consumption is likely to be sensitive towards prices of supplementary or alternate fuels, we also include the average price of kerosene and liquid petroleum gas (LPG)

\footnotetext{
${ }^{5}$ Since Indian households are not faced by a two-part tariff and there is no fixed charge for electricity, the use of average prices in the model does not cause any simultaneity problem in the econometric estimation of the demand functions.
} 
in the estimation of the demand functions. These are also included in the model in order to test the hypothesis of whether these fuels are in anyway complimentary or substitutes to electricity.

Cross-sectional data on appliance prices are not available. However, appliance prices faced by households can, apart from minor regional variations, be regarded as constant. Therefore, they may be excluded from the model without causing bias in estimation (see Halvorsen (1975)).

Two dummy variables are included in the model to capture differences on account of the discrete demographic variable for the age of the head of the household (DAHi). A dummy variable for the number of household members living in the household (DHHS) and the variable dwelling size $(\mathrm{AD})$, are included in the model in order to take into account the effect on electricity consumption of the size of the household. In general, the larger the area of the dwelling, the more the requirement for electrical fixtures such as fans, lights, coolers, etc.

The dummy variable for the size of the town (DTS) is entered in the model, in order to take into account the impact of easier accessibility to a developed electric system and markets for electrical appliances on electricity consumption. The basic hypothesis is that households living in larger cities have greater possibilities to increase their electricity consumption.

The regional dummy variables (DRi) are entered in the model, in order to take into account the impact of regional characteristics such as weather, degree of development and urbanization, social characteristics and habits of individuals on household electricity consumption. For this purpose we define, according to the information contained in our data set, five Indian regions. Thus, four regional dummy or discrete variables are introduced in the model (North, East, South, and West) to capture regional differences in the location of the household for the five different regions. Individuals residing in the states of the North-east 
region are taken as the reference households to avoid singularity due to the use of binary dummy variables in the model.

Estimation of demand function (3) requires the specification of a functional form. While there is no clear consensus in the literature on the functional form that is best suited for estimating household electricity demand, most studies that have adopted a single equation specification have most often used a linear or logarithmic form ${ }^{6}$. The double logarithmic or $\log$ - $\log$ form offers an appropriate functional form for answering questions about price and income elasticities. The major advantage, of course, is that the estimated coefficients amount to elasticities, which are, therefore, assumed to be constant.

The equation to be estimated for each season is:

(2)

$\begin{aligned} \ln E= & \alpha_{0}+\alpha_{P E} \ln P_{E}+\alpha_{P K} \ln P_{K}+\alpha_{P G} \ln P_{G}+\alpha_{Y} \ln Y+\alpha_{A D} \ln A D+\alpha_{D H H S} D H H S \\ & +\alpha_{D T S} D T S+\alpha_{D R 1} D R 1+\alpha_{D R 2} D R 2+\alpha_{D R 3} D R 3+\alpha_{D R 4} D R 4+\alpha_{D A H 1} D A H 1+\alpha_{D A H 2} D A H 2\end{aligned}$

Since it is reasonable to assume that in a cross-section the observed difference in consumption of electricity represents not only variation in the utilization rate but also stock adjustment, estimates based on cross-sectional data are conventionally interpreted as long-run elasticities $^{7}$.

\footnotetext{
${ }^{6}$ In a preliminary analysis, we also explored the possibility of using a linear or semi-log functional form for the estimated equation. However, the econometric specification for these forms suggested that they did not provide the best fit to the data.
}

${ }^{7}$ For a discussion about the interpretation of elasticity estimates with cross-section data see Thomas (1987). 


\section{Data and estimation results}

The household micro data used in this study is provided by the household expenditures survey Round 50 for the year 1993-94 from the National Sample Survey (NSS) conducted by the department of statistics of the Indian government (NSS, 1998). The surveys are canvassed quinquennially to a very large and representative sample of Indian households. The latest in the series of quinquenial rounds is that for the year 1999-2000. However, a great deal of controversy surrounds the data from this round as it for the first time administered a schedule in which information regarding consumption for a 30-day and 7-day recall period was elicited simultaneously from the same sample of households. Thus, reliability of data estimates from this years survey have been questioned and many researchers have advised against making use of the data from this year. For this reason, we make use of data from the next most recent round, which is that for the year 1993-94. The survey for this year contains data separately for a large number of households living in rural and urban areas ${ }^{8}$. This large data set contains information on quantity and value of household consumption with a reference period of the last 30 days preceding the date of the interview. In addition, data on a host of other socio-economic variables is collected through the survey. Prices are determined from the sample data as unit values, or in other words, monetary expenditures divided by physical quantities of consumption. The information for a single household is gathered only for one month. Thus, the households in the three seasonal datasets are not the same. The data set includes 7499 urban households for which information are available for summer months,

\footnotetext{
${ }^{8}$ The official definition of urban areas is based on number of criteria including “(a) the population of the place should be greater than 5000; (b) a density of not less than 400 persons per square km.; (c) three-fourths of the male workers are engaged in non-agricultural pursuits.” [GoI, 2001a].
} 
12020 for which information are available for winter months and 10067 for which information are available for monsoon months.

Tables 2 and 3 gives some statistical details on the variables employed in the estimation of the household demand model for electricity. The statistics reported in these tables on the variables employed in the econometric part of this paper show that the mean values are fairly similar across the three data sets (winter, summer, monsoon). This result is not surprising, because the survey is performed every month over a period of a year by the Indian government using the same sample selection principle. Table 2 also reveals variation, especially in price, across different regions of the country. This can be attributed to differences in the pricing policies of the different State governments. Moreover, the regional disparities are also possibly a reflection of the socio-cultural differences between States owing to different ethnic and communal composition, and differing degrees of development.

\section{Table 2: Description of variables}

\section{Table 3: Description of the dummy variables}

Table 3 shows that a high percentage of Indian households living in urban areas according to our sample live in very large cities (with a population of more than 1 million). Also, there is a higher concentration of sample households in the Western and Southern region of the country, as expected, as these comprise the main industrial belts of the country.

The estimated coefficients and their associated t-values, obtained using an OLS approach, for the three seasonal household electricity demand models are presented in Table 
$4^{9}$. The estimated functions are well behaved. Most of the parameter estimates are statistically significant ${ }^{10}$. The goodness-of- fit $\left(\mathrm{R}^{2}\right)$ measure varies between 0.50 and 0.54 . The explanatory power of the regressions is reasonably good given the individual cross-sectional data. Since electricity consumption and the continuous regressors are in logarithms, the coefficients are interpretable as demand elasticities. The percentage effects for the dummy variables can be derived by exponential transformation of the coefficients.

Table 4: Residential electricity demand estimates (t-ratios in parentheses)

The price elasticity for electricity is significant in all three models and carries the expected sign. The estimated own price elasticity is -0.42 during the winter months, -0.51 during the monsoon months and -0.29 during the summer months. This suggests that a 1 percent increase in the price index of electricity will (ceteris paribus) result in approximately a 0.4-0.5 percent decline in household consumption of electricity during the winter and

\footnotetext{
${ }^{9}$ Prior to carrying out the actual regression estimations, scatter diagrams between the dependent variable and each of the independent continuous variables were plotted for each season as part of an exploratory data analysis.
} In addition, a correlation analysis was undertaken to determine partial correlation coefficients among the independent variables. These were also examined in order to detect if there was potential multicollinearity among any of the independent variables. The examination of the correlation coefficients showed that they were all $<0.7$. In general, if the correlation coefficients between two regressors is greater than $0.8-0.9$ then one can expect that multicollinearity could be a serious problem (Judge et. al. 1982).

${ }^{10}$ Since the sample size is fairly large in our datasets, the coefficients of the regression equations can be expected to be estimated with reasonable precision. 
monsoon months and approximately a 0.3 percent decline during the summer months ${ }^{11}$. This result indicates a price-inelastic demand for electricity and values slightly lower than those reported in previous studies by Bose and Shukla (1999) and Tiwari (2000). Therefore, from an energy point of view we can say that there is little room for discouraging residential electricity consumption, using price increases alone. Finally, these results show that the electricity demand during the summer months is more price-inelastic than the electricity demand during the other seasons of the year. This difference can be explained by the fact that during the summer months, because of the high temperatures, the use of air conditioners and air ventilators is very intense and necessary.

The demand for electricity is responsive in all models to the level of income (Y) with an income elasticity of approximately $0.60-0.64$ across the three seasons. Since this elasticity is below unity, income growth apparently results in a less than proportional increase in electricity demand.

An examination of the coefficients on the price of alternate energy fuels that were included in the model provide cross-price elasticities and show that in general there is a complimentary relationship between electricity and LPG as the coefficient on price of LPG is negative and highly significant in two of the three seasons. However, the coefficient on kerosene price is generally not significant. This result is surprising, as one would expect some degree of substitutability between kerosene and electricity, since the former is also used for lighting purposes. A more detailed interpretation of the cross-price elasticities will probably

\footnotetext{
${ }^{11}$ In order to test whether own price elasticity of demand for electricity varies across different income groups, we included an interaction term between a dummy variable for very high-income households and the own price
} variable in an initial version of the model equation. However, the coefficient on this term was not significant and hence dropped from the model. 
require further analysis and data. To test whether there was any potential econometric problem with estimating the model inclusive of prices for alternate fuels, the estimation was carried out both with and without the price of kerosene and price of LPG and results revealed that coefficients on the other variables were quite stable in both cases.

Dwelling size seems to significantly influence the electricity consumption of urban Indian households. The estimated Dwelling size elasticity is significantly different from 0 at the $99 \%$ confidence level in all three seasonal models and the value of this elasticity is approximately 0.2 . Thus, for instance, a 1 percent increase in the number of squared feet (ceteris paribus) results in about a 0.2 percent increase in household consumption of electricity.

The coefficients of the regional dummy variables indicate that, ceteris paribus, household living in Northern, Southern, Eastern and Western regions have higher electricity consumption than those living in regions of the North-east. These differences can be explained by important differences in the overall level of development of these regions and socio-cultural habits of the inhabitants ${ }^{12}$.

Finally, the degree of urbanity and demographic characteristics of households also significantly influence electricity consumption. For instance, the result on the dummy variable related to the size of the town (DTS) indicates that households living in larger cities show a significantly higher electricity consumption than those living in cities with less than 1 million

\footnotetext{
${ }^{12}$ The initial models estimated also included interaction terms between the regional dummies and price and income variables. These were included in the model in order to test whether there is any variation in income and price elasticities across regions, in addition to the variation observed across seasons. However, the coefficients on these interaction terms were not significant and were hence excluded from the subsequent analysis.
} 
inhabitants. This result confirms the hypothesis that generally larger cities are characterized by more developed markets and electricity distribution systems, and, therefore, more continuous access to electricity and easier access to electrical appliances and equipment as well. The dummy variable for household size is significant and negative in all three seasons and so are the dummies for the age of household head. Therefore, this indicates that houses with a large number of members (greater than 6) and those with younger household heads (less than 45 years old) have lower electricity consumption than those, which have fewer members and older household heads.

A comparison of the elasticity estimates from this study with those of other studies reveals that in general, the values of the own price elasticities found in this study are lower than those obtained in other studies for India using aggregate data ${ }^{13}$. The results for income elasticities of demand confirm the results obtained in other studies performed for India using aggregate data. The values obtained in our study are lower than one, as expected, but higher than those obtained in similar studies for highly developed countries ${ }^{14}$.

\section{Summary and conclusions}

The paper provides results of the estimation of three seasonal linear econometric models of electricity demand for urban India using a rich database consisting of information at the individual household level. The models are used to determine the responsiveness of electricity consumption to own price, income, price of alternate fuels and variables relating to

\footnotetext{
${ }^{13}$ See Bose \& Shukla (1999), Tiwari (2000).

${ }^{14}$ See for instance D. Hawdon (1992), M. Filippini (1999), Andersson and Damsgaard, (2000), Leth-Petersen,
} 
demographic and geographic characteristics of households, for three different seasons summer, winter and monsoon. The estimated models demonstrate the importance of household and other geographical characteristics in determining electricity demand, something which is not possible using aggregate data alone.

The results show that the estimated equation is fairly stable over the three different seasons. However, a great degree of heterogeneity in household electricity demands at the individual household level is evident.

The models also provide estimates of income, own and cross price elasticities of electricity demand for urban India. As would be expected, the estimates for income elasticities show that electricity is a necessity. However, the relatively high value for this elasticity confirm that with further economic development of the country, one can expect to see a rise in the electricity consumption of households. The seasonal analysis shows that demand is income inelastic in all three seasons and the elasticity is fairly constant across the seasons. In contrast, there appears to be considerable seasonal variation in own-price elasticities for electricity, with the price elasticity in summer being significantly lower than that observed during the other seasons of the year. However, electricity is also found to be price inelastic in all three models. In other words, future increases in the price of electricity are likely to lead to only a small drop in the quantity demanded and hence a pricing policy alone is not likely to be effective in curbing future demand. Estimates of the cross price elasticities show that consumption of electricity is somewhat complimentary to LPG, that is, a rise in the LPG price results in a slight fall in electricity demand. The coefficient on the kerosene price term was generally insignificant in the models estimated.

Significant effects are estimated for regional variations in electricity consumed. The results also indicate that area of household dwelling unit and demographic characteristics 
(such as household size and age of the head of the household) have significant effects on electricity consumption in urban India. 


\section{References}

Andersson, B. and Damsgaard, N., (2000), Residential Electricity Use - Demand Estimations Using Swedish Micro Data. Working Paper Stockholm School of Economics.

Becker, G. S., (1965), A Theory of the Allocation of Time. Economic Journal 75, S, 493-517.

Bose, R. K. and M. Shukla (1999), Elasticities of electricity demand in India. Energy Policy 27(3), $137-146$.

CMIE, (1996), India's Energy Sector. Centre for Monitoring the Indian Economy Mumbai, India.

CSO (2000), Energy Statistics. Central Statistical Organisation, Department of Statistics, Government of India. New Delhi.

Deaton, A. and Muellbauer, J., (1980), Economics and consumer behavior. Cambridge University Press, Cambridge, UK.

Dubin, J. A., (1985), Consumer Durable Choice and the Demand for Electricity. North Holland Publishers.

Filippini, M., (1999), Swiss Residential Demand for Electricity. Applied Economic Letters, 6 (8).

Flaig, G., (1990), Household Production and the Short-Run and Long-Run Demand for Electricity. Energy Economics 12, 116-121.

GoI (2001a). Provisional Population Totals, Census of India. Government of India. New Delhi. 
GoI (2001b). Report on the working of the State Electricity Boards, Planning Commission, New Delhi.

Halvorsen, R., (1975), Residential Demand for Electric Energy. The Review of Economics and Statistics 85, 12-18.

Hawdon, D. edited (1992), Energy Demand - Evidence and Expectations. Surrey University Press, London, UK.

Judge, G., Hill, R., Griffiths, W., Luetkepohl, H., Lee, T., (1982), Introduction to the Theory and Practice of Econometrics. Second Ed. John Wiley and Sons Inc. New York.

Jung, T. Y., (1993), Ordered logit model for residential electricity demand in Korea. Energy Economics 15(3), 205-209.

Leth-Petersen, S., (2001), Micro Evidence on Household Energy Consumption. AKF Memo, Danish Energy Agency, Denmark.

Muth, R. F., (1966), Household production and consumer demand functions. Econometrica 34, 699708.

NCAER, (1999), India Human Development Report. National Council for Applied Economic Research. Oxford University Press. New Delhi.

Nesbakken, R., (1999), Price sensitivity of residential energy consumption in Norway. Energy Economics 21(6), 493-515. 
NSSO (1998), 50th Round of Household Schedule 1.0 Consumer Expenditure Survey Data, National Sample Survey Organisation, Department of Statistics, Government of India.

Roy, J., (1992), Demand for Energy in Indian Industries - a Quantitative Approach. Daya Publishers, Delhi, India.

Sengupta, R., (1993), Energy Modelling for India - Towards a Policy for Commercial Energy. Planning Commission, Government of India.

TERI, (1999), TERI Energy Data Directory and Yearbook 1998-99 (TEDDY), TERI (Tata Energy Research Institute). New Delhi.

Thomas, R.L., (1987) Applied Demand Analysis. Longman Publishers.

Tiwari, P. (2000), Architectural, Demographic, and Economic Causes of Electricity Consumption in Bombay, Journal of Policy Modelling 22(1): 81-98

Uri, N.D., (1979), Energy demand and interfuel substitution in India. European Economic Review 12, 181-190. 
Table 1: Consumer category - wise average electricity tariffs in Paise/Kwh

\begin{tabular}{|l|l|l|l|l|}
\hline & $\mathbf{1 9 9 6 - 9 7}$ & $\mathbf{1 9 9 7 - 9 8}$ & $\mathbf{1 9 9 8 - 9 9}$ & $\mathbf{1 9 9 9 - 2 0 0 0}$ \\
\hline Cost of supply & 215.6 & 239.7 & 263.1 & 305.1 \\
\hline Average tariff & 165.3 & 180.3 & 186.8 & 207.0 \\
\hline Average agricultural tariff & 21.2 & 20.2 & 21.0 & 22.6 \\
\hline Average domestic tariff & 105.7 & 136.2 & 139.1 & 160.7 \\
\hline Average commercial tariff & 239.1 & 293.6 & 330.2 & 369.9 \\
\hline Average Industry tariff & 275.5 & 312.7 & 322.8 & 342.0 \\
\hline Average traction tariff & 346.8 & 382.2 & 410.3 & 415.3 \\
\hline Outside state & 151.4 & 138.1 & 163.8 & 190.1 \\
\hline Overall average & 165.3 & 180.3 & 186.8 & 207.0 \\
\hline
\end{tabular}

Source: GoI, 2001 
Table 2: Description of variables

\begin{tabular}{|c|c|c|c|c|c|c|c|c|c|c|c|c|c|c|c|}
\hline & \multicolumn{5}{|c|}{ Dataset for winter months } & \multicolumn{5}{|c|}{ Dataset for summer months } & \multicolumn{5}{|c|}{ Dataset for monsoon months } \\
\hline Variables & North & South & East & West & $\mathrm{N}$-east & North & South & East & West & $\mathrm{N}$-east & North & South & East & West & $\mathrm{N}$-east \\
\hline $\begin{array}{l}\text { Household } \\
\text { electricity } \\
\text { consumption } \\
\text { (E) } \\
\text { kWh/month } \\
\end{array}$ & 55.02 & 54.92 & 55.88 & 68.30 & 21.32 & 52.13 & 50.86 & 55.95 & 74.67 & 22.33 & 56.58 & 50.99 & 52.65 & 71.31 & 23.00 \\
\hline $\begin{array}{l}\text { Electricity } \\
\text { price }\left(\mathrm{P}_{\mathrm{E}}\right) \\
\text { Rupees/kWh }\end{array}$ & 1.59 & 0.83 & 0.97 & 1.04 & 0.90 & 1.32 & 0.83 & 1.01 & 1.00 & 0.82 & 1.55 & 0.81 & 0.97 & 1.01 & 0.84 \\
\hline $\begin{array}{l}\text { Kerosene } \\
\text { price }\left(\mathrm{P}_{\mathrm{K}}\right) \\
\text { Rupees/litre }\end{array}$ & 5.31 & 5.90 & 6.07 & 4.44 & 5.78 & 5.21 & 5.94 & 6.00 & 4.35 & 5.66 & 5.27 & 5.74 & 6.05 & 4.39 & 5.55 \\
\hline $\begin{array}{l}\text { LPG price } \\
\left(\mathrm{P}_{\mathrm{G}}\right) \\
\text { Rupees/kg }\end{array}$ & 6.65 & 6.88 & 6.94 & 6.75 & 6.33 & 6.91 & 6.97 & 7.09 & 6.86 & 6.46 & 6.58 & 6.81 & 6.83 & 6.58 & 6.25 \\
\hline $\begin{array}{l}\text { Dwelling size } \\
\text { (AD) } \\
\text { Square feet }\end{array}$ & 500.62 & 441.35 & 446.01 & 451.52 & 461.52 & 498.70 & 414.12 & 481.38 & 456.02 & 557.42 & 388.15 & 440.45 & 452.59 & 434.05 & 439.68 \\
\hline $\begin{array}{l}\text { Total } \\
\text { expenditure } \\
\text { per household } \\
(Y) \\
\text { Rupees/mont } \\
\text { h }\end{array}$ & $\begin{array}{c}2628.0 \\
0\end{array}$ & $\begin{array}{c}2093.6 \\
5\end{array}$ & $\begin{array}{c}2310.2 \\
1\end{array}$ & $\begin{array}{c}2407.4 \\
8\end{array}$ & $\begin{array}{c}2178.2 \\
0\end{array}$ & $\begin{array}{c}2420.3 \\
0\end{array}$ & $\begin{array}{c}1983.9 \\
8\end{array}$ & $\begin{array}{c}2336.6 \\
2\end{array}$ & $\begin{array}{c}2513.8 \\
6\end{array}$ & $\begin{array}{c}2460.3 \\
2\end{array}$ & $\begin{array}{c}2431.2 \\
5\end{array}$ & $\begin{array}{c}2006.7 \\
4\end{array}$ & $\begin{array}{c}2159.4 \\
5\end{array}$ & $\begin{array}{c}2353.6 \\
2\end{array}$ & $\begin{array}{c}2384.0 \\
5\end{array}$ \\
\hline
\end{tabular}


Table 3: Description of the dummy variables

\begin{tabular}{|l|l|l|l|l|}
\hline Variable & $\begin{array}{l}\text { Condition for which the variable } \\
\text { value is equal to one }\end{array}$ & $\begin{array}{l}\text { Frequency } \\
(\%) \\
\text { Winter }\end{array}$ & $\begin{array}{l}\text { Frequen } \\
\text { cy }(\%) \\
\text { Summer }\end{array}$ & $\begin{array}{l}\text { Frequency } \\
(\%) \\
\text { Monsoon }\end{array}$ \\
\hline DTS & $\begin{array}{l}\text { Households living in a city with } \\
\text { more than 1 million inhabitants }\end{array}$ & 26.5 & 23.5 & 22.7 \\
\hline DR1 & Households living in region East & 13.3 & 11.6 & 10.8 \\
\hline DR2 & Households living in region West & 30.7 & 28.3 & 30.8 \\
\hline DR3 & Households living in region South & 27.4 & 33.9 & 31.5 \\
\hline DR4 & Households living in region North & 26.8 & 24.4 & 25.6 \\
\hline DHHS & $\begin{array}{l}\text { Households with more than 6 } \\
\text { members }\end{array}$ & 16.7 & 15.5 & 16.9 \\
\hline DAH1 & $\begin{array}{l}\text { Households where the head is less } \\
\text { than 30 years of age }\end{array}$ & 14.1 & 13.9 & 14.3 \\
\hline DAH2 & $\begin{array}{l}\text { Households where the head is } \\
\text { between 30 and 45 years of age }\end{array}$ & 42.6 & 41.4 & 42.2 \\
\hline
\end{tabular}


Table 4: Residential electricity demand estimates (t-ratios in parentheses)

\begin{tabular}{|c|c|c|c|}
\hline Variable & $\begin{array}{l}\text { Model } \\
\text { Winter months }\end{array}$ & $\begin{array}{l}\text { Model } \\
\text { Summer months }\end{array}$ & $\begin{array}{l}\text { Model } \\
\text { Monsoon } \\
\text { months }\end{array}$ \\
\hline Constant & $\begin{array}{l}-2.081 * * * \\
(-13.71)\end{array}$ & $\begin{array}{l}-2.844 * * * \\
(-14.88)\end{array}$ & $\begin{array}{l}-0.914 * * * \\
(-5.20)\end{array}$ \\
\hline $\ln \mathrm{Y}$ & $\begin{array}{l}0.637 * * * \\
(65.84)\end{array}$ & $\begin{array}{l}0.632 * * * \\
(51.92)\end{array}$ & $\begin{array}{l}0.604 * * * \\
(57.80)\end{array}$ \\
\hline $\ln \mathrm{P}_{\mathrm{E}}$ & $\begin{array}{l}-0.416^{* * * *} \\
(-26.85)\end{array}$ & $\begin{array}{l}-0.292 * * * \\
(-14.30)\end{array}$ & $\begin{array}{l}-0.507 * * * \\
(-29.83)\end{array}$ \\
\hline $\ln \mathrm{P}_{\mathrm{K}}$ & $\begin{array}{l}-0.006 \\
(-0.22)\end{array}$ & $\begin{array}{l}-0.037 \\
(-1.09)\end{array}$ & $\begin{array}{l}0.058^{*} \\
(1.95)\end{array}$ \\
\hline $\ln P_{G}$ & $\begin{array}{l}-0.273^{* * *} \\
(-4.15)\end{array}$ & $\begin{array}{l}0.260 * * \\
(2.92)\end{array}$ & $\begin{array}{l}-0.652 \text { *** } \\
(-8.81)\end{array}$ \\
\hline $\ln A D$ & $\begin{array}{l}0.223 * * * \\
(32.75)\end{array}$ & $\begin{array}{l}0.210 * * * \\
(22.58)\end{array}$ & $\begin{array}{l}0.175^{* * *} \\
(24.65)\end{array}$ \\
\hline DHHS & $\begin{array}{l}-0.089 * * * \\
(-6.28)\end{array}$ & $\begin{array}{l}-0.119 * * * \\
(-6.51)\end{array}$ & $\begin{array}{l}-0.069 * * * \\
(-4.16)\end{array}$ \\
\hline DAH1 & $\begin{array}{l}-0.181 * * * \\
(-10.47)\end{array}$ & $\begin{array}{l}-0.170 * * * \\
(-7.62)\end{array}$ & $\begin{array}{l}-0.263 * * * \\
(-12.81)\end{array}$ \\
\hline DAH2 & $\begin{array}{l}-0.060 * * * \\
(-5.49)\end{array}$ & $\begin{array}{l}-0.089 * * * \\
(-6.43)\end{array}$ & $\begin{array}{l}-0.099 * * * \\
(-7.58)\end{array}$ \\
\hline DTS & $\begin{array}{l}0.355 * * * \\
(27.22)\end{array}$ & $\begin{array}{l}0.311 * * * \\
(18.46)\end{array}$ & $\begin{array}{l}0.361 * * * \\
(22.51)\end{array}$ \\
\hline DR1 & $\begin{array}{l}0.406 * * * \\
(18.77)\end{array}$ & $\begin{array}{l}0.429 * * * \\
(13.69)\end{array}$ & $\begin{array}{l}0.480 * * * \\
(15.34)\end{array}$ \\
\hline DR2 & $\begin{array}{l}0.196 * * * \\
(9.65)\end{array}$ & $\begin{array}{l}0.109 * * * \\
(3.85)\end{array}$ & $\begin{array}{l}0.148 * * * \\
(4.97)\end{array}$ \\
\hline DR3 & $\begin{array}{l}0.403 * * * \\
(17.57)\end{array}$ & $\begin{array}{l}0.360^{* * * *} \\
(11.32)\end{array}$ & $\begin{array}{l}0.292 * * * \\
(8.91)\end{array}$ \\
\hline DR4 & $\begin{array}{l}0.402 * * * \\
(18.03)\end{array}$ & $\begin{array}{l}0.373 * * * \\
(11.49)\end{array}$ & $\begin{array}{l}0.428^{* * * *} \\
(13.41)\end{array}$ \\
\hline $\mathrm{R}^{2}$ & 0.54 & 0.52 & 0.50 \\
\hline
\end{tabular}


Table A: States and regions

\begin{tabular}{|l|l|}
\hline North East & $\begin{array}{l}\text { Assam, Arunachal Pradesh, Manipur, } \\
\text { Meghalaya, Mizoram, Nagaland, Tripura }\end{array}$ \\
\hline South & $\begin{array}{l}\text { Andhra Pradesh, Karnataka, Kerala, } \\
\text { Tamil Nadu, Lakshwadeep, } \\
\text { Pondicherrry }\end{array}$ \\
\hline West & $\begin{array}{l}\text { Goa, Gujarat, Madhya Pradesh, } \\
\text { Maharashtra, Dadra \& Nagar Haveli, } \\
\text { Daman \&Diu }\end{array}$ \\
\hline North & $\begin{array}{l}\text { Harayana, Himachel Pradesh, Jammu \& } \\
\text { Kashmir, Punjab, Rajasthan, } \\
\text { Chandigarh, Delhi, Uttar Pradesh }\end{array}$ \\
\hline East & $\begin{array}{l}\text { Andaman \& Nicobar Islands, Bihar, } \\
\text { Orissa, Sikkim, West Bengal }\end{array}$ \\
\hline
\end{tabular}

